\title{
Social relationships and reproductive performance in group-living arctic blue foxes
}

\author{
HANNU KORHONEN and SAKARI ALASUUTARI
}

KORHONEN, H. ${ }^{1}$ \& AlasUUtARI, S. ${ }^{2}$ 1994. Social relationships and reproductive performance in group-living arctic blue foxes. Agricultural Science in Finland 3: 49-58. ('Agricultural Research Centre of Finland, Fur Farming Research Station, FIN-69100 Kannus, Finland and ${ }^{2}$ University of Helsinki, Muddusjärvi Experimental Farm, FIN99910 Kaamanen, Finland.)

\begin{abstract}
The aim of the present work was to study social relationships and reproductivity in captive arctic blue fox groups of different genetic origin. The social status of the individuals among groups remained constant during autumn and early winter. Males typically dominated over females in the groups. Males also had higher body weights and more social contacts than females. The locomotor activity of the animals increased during the breeding season, especially in the case of males. Urinary marking had a significant importance during the breeding season, being most pronounced in dominant males. No synchronization was observed in the heat development of females despite some kinship. Behaviours such as escape attempts, bitings and increased aggressiveness occurred in March-April as a result of increasing social tension combined with reproductive behaviour. Whelping success varied depending on group composition. Some of the non-breeding and breeding females were observed to act as communal nursing helpers.
\end{abstract}

Key words: dominance, hierarchy, social behaviour

\section{Introduction}

The arctic fox (Alopex lagopus) has been previously considered to have relatively solitary living habits in the wild (FoX 1969, BANFIELD 1977). Recently, however, social characteristics in the behaviour of this species have been emphasized. During the denning season, for instance, reproducing arctic foxes have been observed to form social family groups consisting of adult males and females with their progeny (HERSTEINSSON and MACDONALD 1982, MACDONALD 1984). Social interactions between members of the family in the dens seem to be limited, however (GARROTT et al. 1984). Occasionally, also supplemental, non-breeding vixens have been observed at rearing dens (EBERHARDT et al. 1983), where some of them act as communal nursing helpers (HERSTEINSSON and MACDONALD 1982, HERSTEINSSON 1991, MACDONALD 1984).

In captivity, arctic blue foxes form a type of social organization characterized by observable dominance relationships when reared in groups (KORHONEN and ALASUUTARI 1991a,b, 1992a,b). The rank order of a group is often related to age and Sex (WAKELY and MALLORY 1988, ANGERBJÖRN et al. 1991). During the nursing season, there have been some observations of co-operative nursing of pups with extra adults serving as helpers (KULLBERG and ANGERBJÖRN 1991). Thus, the recent data both from the wild and from captivity support 
the hypothesis of the arctic fox being an even more social animal than has been previously believed. More studies are, however, needed in order to further confirm this conclusion.

The objective of the present study was to examine the social relationships and reproductive success among captive arctic blue foxes (Alopex lagopus) with different group compositions housed in ground enclosures.

\section{Material and methods}

\section{Subjects and general management}

The experiments were carried out at the Muddusjärvi Experimental Farm in Finnish Lapland $\left(69^{\circ} \mathrm{N}\right.$, $27^{\circ} \mathrm{E}$ ). At weaning, three different groups of farmborn arctic blue foxes (Alopex lagopus) were formed as follows: Group 1: 3 males (A,A,B) and 3 females $(A, A, C)$ housed in an enclosure measuring $17 \mathrm{~m}$ long $x 8 \mathrm{~m}$ wide. Group 2: one male (D,) and 3 females $(\mathrm{E}, \mathrm{F}, \mathrm{E})$ housed in an enclosure measuring $11 \mathrm{~m}$ long $x 8 \mathrm{~m}$ wide. Group 3: 3 males $(\mathrm{G}, \mathrm{H}, \mathrm{I})$ and 3 females $(\mathrm{J}, \mathrm{J}, \mathrm{J})$ housed in an enclosure measuring $11 \mathrm{~m}$ long $\times 8 \mathrm{~m}$ wide. The capital letters A-J represent the different litters from which the foxes originated. The animals in Groups 1, 2 and 3 were born on May 7-8, May 12-13 and May 10-16, respectively. Each enclosure contained 3-4 wooden nestboxes measuring $70 \mathrm{~cm}$ long $x 40 \mathrm{~cm}$ wide $\mathrm{x} 40$ cm high (Fig. 1).

\section{Experimental treatments and observations}

The animals were weighed 6 times during the course of the experiments. They were fed once a day; the daily feed portion was about $550 \mathrm{~g}$ per animal until December 1, and about $350 \mathrm{~g}$ after that. During the breeding season the heat development in females was monitored by evaluation of vulval swelling and by measuring the electrical resistance in the vaginal tract (MÖLLER 1980).

The animals were observed 4-5 times weekly for periods lasting about 30 minutes to estimate their social status and contacts (dominant/submissive behaviour, based on avoiding behaviours when interacting with another fox) (WAKELY and MALLORY 1988, KORHONEN and ALASUUTARI 1992a). Twice weekly the observations were made at feeding time (lasting about 15 minutes) when the occurrence of mutual contacts and aggressions were most pronounced. The individual eating order, as well as the number and outcome of challenges made by the foxes, was observed as described by WAKELY and MALLORY (1988). The social contacts of the animals were also monitored by a videocamera (Panasonic NV-G1) during a 4-hour periods twice a month. The daily activity and urinary marking behaviour of the animals was recorded by visual scan-

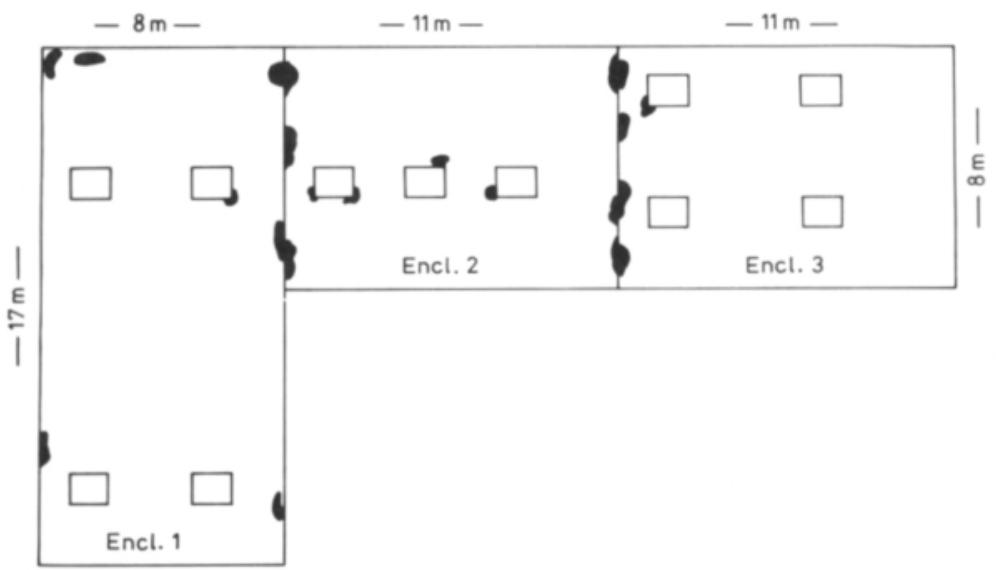

Fig. 1. Schematic picture of the experimental enclosures. Dark dots represent the sites of urine markings. 
Table 1. Development of body weights $(\mathrm{kg})$ in the experimental enclosures.

\begin{tabular}{lcccccc}
\hline & Aug 5 & Aug 31 & Oct 20 & Dec 4 & Jan 28 & Mar 15 \\
\hline ENCLOSURE 1 & & & & & & \\
Male-1 & 4.3 & 5.5 & 5.9 & 9.0 & 9.0 & 6.9 \\
Male-2 & 5.2 & 6.2 & 6.7 & 9.8 & 9.9 & 8.7 \\
Male-3 & 5.3 & 6.9 & 7.5 & 11.1 & 10.8 & 8.3 \\
Female-1 & 4.2 & 4.9 & 5.2 & 7.9 & 7.9 & 7.0 \\
Female-2 & 4.3 & 5.0 & 5.8 & 8.2 & 7.7 & 6.8 \\
Female-3 & 4.5 & 5.1 & 5.0 & 7.8 & 6.9 & 6.1 \\
ENCLOSURE 2 & & & & & \\
Male-1 & 4.8 & 5.6 & 6.6 & 9.2 & 9.3 & 7.4 \\
Female-1 & 4.8 & 5.0 & 5.4 & 7.5 & 7.7 & 6.5 \\
Female-2 & 4.6 & 5.8 & 6.1 & 8.3 & 8.4 & 6.7 \\
Female-3 & 5.2 & 5.9 & 6.1 & 8.5 & 7.9 & 6.4 \\
ENCLOSURE 3 & & & & & & \\
Male-1 & 4.0 & 5.3 & 5.8 & 8.3 & 8.8 & 7.1 \\
Male-2 & 3.9 & 5.0 & 5.2 & 7.4 & 7.9 & 6.8 \\
Male-3 & 4.5 & 5.8 & 6.4 & 9.3 & 9.5 & 7.7 \\
Female-1 & 3.4 & 3.9 & 4.3 & 6.1 & 6.8 & 5.7 \\
Female-2 & 3.6 & 4.6 & 4.6 & 6.5 & 6.8 & 5.9 \\
Female-3 & 3.8 & 4.7 & 5.1 & 7.1 & 7.5 & 6.7 \\
\hline
\end{tabular}

ning observations (at 1-minute intervals) during three 24-hour periods: September 1-3, January 1921 and March 16-18.

Statistical analyses were carried out in SAS using analyses of variance (ANOVA) and the Chi square test.

\section{Results}

\section{Weight gain}

At the beginning of the experiments, the body weight differences of the animals in each group were within a frame of about $1 \mathrm{~kg}$ (Table 1). During autumn, the weights of the males tended to increase faster compared to the females. Therefore, males also reached higher mid-winter weights than females $(\mathrm{p}<0.05)$. Maximum weights were achieved in December-January when the weight differences between the heaviest and lightest individuals among the groups were as high as $3.3 \mathrm{~kg}$. After January, weights started to decline markedly, even by as much as $2.5 \mathrm{~kg}$ within a 1.5 -month period.

\section{Behavioural activity}

A summary of behavioural activity observations is given in Table 2. Already in September, clear differences $(p<0.05)$ were apparent in the locomotor activities of the individuals within the groups. In enclosures 1 and 2, no marked differences existed betwen the sexes. On the other hand, in enclosure 3 the males were more active than the females $(\mathrm{p}<0.05)$. Furthermore, no marked differences in average group activity were found between the enclosures; the mean activity values for enclosures 1 , 2 and 3 were $35.5,33.1$ and $32.2 \%$ /day, respectively. The number of urinations was low (from 1 to 4 times daily) in all animals during this period.

In January, locomotor activity (24.6\%/day on an average) was significantly $(\mathrm{p}<0.05)$ lower than in September (33.7\%/day) when the foxes were juveniles. The activities for enclosures 1,2 and 3 were $27.0,20.7$ and $24.3 \% /$ day, respectively. No statistically significant differences in activity were found between males (24.9\%/day) and females $(24.2 \%$ / day). Urinary markings were still low.

Locomotor activity increased $(\mathrm{p}<0.05)$ in March (37.6\%/day) compared to both January and Sep- 
Table 2. Locomotor activity $(\% / 24 \mathrm{~h})$, number of individual urinations (urine marks $/ 24 \mathrm{~h}$ ) and social status. The data for each month are based on 3-day observations: Sept 1-3, Jan 19-21, and Mar 16-18. Social status represents the hierarchical positions among the group in mid-March. I: social status estimated according to dominant/submissive behaviour observations made during daytime and in feeding situations. II: social status according to number of daily mutual contacts (based on Table 3). $1=$ most dominant, $6=$ least dominant. The social status of an individual shows its place in the rank order of the group.

\begin{tabular}{|c|c|c|c|c|c|c|c|c|c|}
\hline & \multicolumn{3}{|c|}{ Locomotor activity } & \multicolumn{3}{|c|}{ Number of urinations } & \multicolumn{2}{|c|}{ Status } & \multirow{2}{*}{ Litter } \\
\hline & Sept & Jan & Mar & Sept & Jan & Mar & I & II & \\
\hline \multicolumn{10}{|c|}{ ENCLOSURE 1} \\
\hline Male-1 & 30.0 & 29.6 & 45.3 & 1 & 1 & 21 & 2 & 2 & A \\
\hline Male-2 & 42.1 & 28.2 & 41.0 & 3 & 2 & 6 & 3 & 3 & A \\
\hline Male-3 & 35.0 & 22.9 & 42.1 & 1 & 3 & 32 & 1 & 1 & B \\
\hline Female-1 & 36.1 & 25.2 & 24.8 & 1 & 3 & 1 & 6 & 6 & A \\
\hline Female-2 & 30.6 & 28.2 & 34.6 & 2 & 2 & 7 & 4 & 5 & A \\
\hline Female-3 & 39.7 & 30.5 & 30.6 & 1 & 1 & 2 & 5 & 4 & $\mathrm{C}$ \\
\hline \multicolumn{10}{|c|}{ ENCLOSURE 2} \\
\hline Male-1 & 30.1 & 20.3 & 32.3 & 1 & 4 & 142 & 1 & 1 & D \\
\hline Female-1 & 39.8 & 24.4 & 49.2 & 4 & 2 & 12 & 2 & 2 & $\mathrm{E}$ \\
\hline Female-2 & 35.3 & 14.9 & 16.2 & 3 & 1 & 1 & 3 & 3 & $\mathrm{~F}$ \\
\hline Female-3 & 27.0 & 23.2 & 23.8 & 1 & 9 & 29 & 4 & 4 & $\mathrm{E}$ \\
\hline \multicolumn{10}{|c|}{ ENCLOSURE 3} \\
\hline Male-1 & 33.0 & 20.1 & 53.7 & 1 & 3 & 15 & 2 & 3 & G \\
\hline Male-2 & 37.2 & 19.6 & 36.6 & 2 & 2 & 10 & 3 & 2 & $\mathrm{H}$ \\
\hline Male-3 & 39.2 & 33.7 & 40.7 & 2 & 1 & 40 & 1 & 1 & I \\
\hline Female-1 & 19.7 & 24.7 & 34.6 & 1 & 1 & 1 & 6 & 6 & $\mathbf{J}$ \\
\hline Female-2 & 33.5 & 24.8 & 48.4 & 2 & 2 & 1 & 4 & 4 & $\mathbf{J}$ \\
\hline Female-3 & 30.5 & 22.6 & 47.9 & 1 & 2 & 1 & 5 & 5 & $\mathbf{J}$ \\
\hline
\end{tabular}

tember. Males were now more active (41.7\%/day) than females (34.4\%/day). The activities for enclosures 1,2 and 3 were $36.4,30.4$ and $43.7 \%$ /day, respectively. A dramatic increase in urinary activity was observed; especially the dominant males in each enclosure were intensive urine markers (Table 2 ). For the females of enclosures 1 and 3 the increase was almost zero, but for those in enclosure 2 the increase was pronounced. It was not possible to estimate the intensivity of locomotor activity with our methods.

The sites of urinary marking became rather fixed as the breeding season approached, as shown by Fig. 1. Most often the urine was directed close to the wall of the neighbouring enclosure. The foxes of enclosure 2 had the highest total marking intensity due to the two neighbouring walls (Table 2, Fig. 1).

\section{Social relationships and rank order}

Social relationships remained constant in each group throughout the autumn and early winter. However, some changes occurred at the onset of the breeding season. In enclosure 1, the social structure was the same both in January and in March (Table 3 ). In enclosure 2 , the number of social contacts markedly decreased in females 2 and 3 during March. The most prominent changes occurred in enclosure 3 ; the social status of males 1 and 2 changed, and the lowest female in January (female F-2) became the most dominant female in March (Tables 2 and 3).

The total number of daily social contacts within the group decreased in enclosures 1 and 2 from 250 to 150 and from 130 to 63 , respectively (January vs. March). In enclosure 3, on the other hand, the num- 
Table 3. Numbers of social contacts (per $24 \mathrm{~h}$ ) between group members. The first column for each animal represents the data from Jan 19-21 and the second from Mar 16-18. Each social contact represents a situation when an encounter of two individuals is supported by clear visual status signals and/or agonistic interaction supported by dominant/submissive behaviour.

\begin{tabular}{lrrrrrrrrrrrr}
\hline & Male-1 & \multicolumn{1}{c}{ Male-2 } & \multicolumn{2}{c}{ Male-3 } & Female-1 & Female-2 & \multicolumn{2}{r}{ Female-3 } \\
\hline Encl.1 & & & & & & & & & & & & \\
Male-1 & - & - & 4 & 11 & 1 & 12 & 11 & 3 & 5 & 6 & 21 & 5 \\
Male-2 & 4 & 11 & - & - & 14 & 7 & 6 & 1 & 4 & 0 & 13 & 0 \\
Male-3 & 1 & 12 & 14 & 7 & - & - & 2 & 2 & 4 & 2 & 28 & 25 \\
Female-1 & 11 & 3 & 6 & 1 & 2 & 2 & - & - & 1 & 0 & 4 & 1 \\
Female-2 & 5 & 6 & 4 & 0 & 4 & 2 & 1 & 0 & - & - & 7 & 0 \\
Female-3 & 21 & 5 & 13 & 0 & 28 & 25 & 4 & 1 & 7 & 0 & - & 0 \\
\hline & 42 & 37 & 41 & 19 & 49 & 48 & 24 & 7 & 21 & 8 & 73 & 31
\end{tabular}

$\begin{array}{lrrrrrrrr}\text { Encl.2 } & & - & 22 & 26 & 12 & 3 & 5 & 0 \\ \text { Male-1 } & - & - & - & - & 4 & 1 & 19 & 0 \\ \text { Female-1 } & 22 & 26 & 4 & 1 & - & - & 3 & 3 \\ \text { Female-2 } & 12 & 3 & 19 & 0 & 3 & 0 & - & - \\ \text { Female-3 } & 5 & 0 & 45 & 27 & 19 & 4 & 27 & 3\end{array}$

\begin{tabular}{|c|c|c|c|c|c|c|c|c|c|c|c|c|}
\hline \multicolumn{13}{|l|}{ Encl. 3} \\
\hline Male-1 & & - & 3 & 4 & 10 & 11 & 10 & 1 & 1 & 2 & 6 & 6 \\
\hline Male-2 & 3 & 4 & & - & 7 & 14 & 3 & 4 & 4 & 18 & 4 & 13 \\
\hline Male-3 & 10 & 11 & 7 & 14 & - & - & 18 & 2 & 3 & 27 & 6 & 6 \\
\hline Female-1 & 10 & 1 & 3 & 4 & 18 & 2 & - & - & 5 & 3 & 11 & 7 \\
\hline Female-2 & 1 & 2 & 4 & 18 & 3 & 27 & 5 & 3 & - & - & 1 & 4 \\
\hline Female-3 & 6 & 6 & 4 & 13 & 6 & 6 & 11 & 7 & 1 & 4 & - & - \\
\hline & 30 & 24 & 21 & 53 & 44 & 60 & 39 & 17 & 14 & 54 & 28 & 36 \\
\hline
\end{tabular}

ber of social contacts increased from 176 to 244 (January vs. March). The estimated social status of the individuals among the experimental groups was rather similar when compared by both dominant/ submissive behaviour observations and by the daily number of mutual social contacts in mid-March (Table 2). The social status of each individual shows its place in the rank order of the group.

\section{Aggressive encounters and escapings}

Aggressive behaviour was not observed during autumn and early winter. However, from January 20 onwards, several aggressive contacts occurred. Males M-1 and M-2 were occasionally aggressive in enclosure 1 and females F-3, F-2 and F-1 in enclosure 2. In enclosure 3, most aggressions were observed between males M-2 and M-3. In each enclosure, bitings led to limping of backfoot of lower-ranking animals, which lasted several weeks.

Escapes from the enclosures occurred during and after the breeding season. Male M-2 escaped from enclosure 1 and female F-1 both from enclosures 2 and 3 . They were all returned to the original enclosures.

\section{Development of oestrus and matings}

All of the females showed visible heat development (Table 4). There was no synchronization in the heat cycles of females in spite of some kinship. Female F-1 in enclosure 2 was the first to come into heat and also the first to mate (March 29). The next one was F-2 of enclosure 1 mated by male M-1, fol- 
Table 4. Vulval swelling $(X=$ low, $X X=$ medium and $X X X=$ intense; represent the intensity $)$ and electrical resistance in the vaginal tract (ohm) in experimental females. * mating observed, ** estimated mating day according to electrical resistance values (MÖLLER 1980) and/or visually observed pregnancy.

\begin{tabular}{|c|c|c|c|c|c|c|c|c|c|}
\hline \multirow[t]{2}{*}{ Date } & \multicolumn{3}{|c|}{ Enclosure 1} & \multicolumn{3}{|c|}{ Enclosure 2} & \multicolumn{3}{|c|}{ Enclosure 3} \\
\hline & F-1 & $F-2$ & $\mathrm{~F}-3$ & F-1 & $F-2$ & F-3 & F-1 & $\mathrm{F}-2$ & F-3 \\
\hline \multirow{5}{*}{$\begin{array}{r}\text { Mar } 23 \\
24 \\
26 \\
28 \\
29\end{array}$} & - & $\mathrm{X}$ & $\mathrm{XX}$ & 415 & $\mathrm{X}$ & $\mathrm{X}$ & - & - & - \\
\hline & - & $\mathrm{X}$ & 115 & 400 & $\mathrm{X}$ & $\mathrm{X}$ & - & - & - \\
\hline & $\mathrm{X}$ & $\mathrm{x}$ & $\mathrm{XX}$ & 550 & $\mathrm{XX}$ & $\mathrm{x}$ & - & - & - \\
\hline & $\mathrm{X}$ & $\mathrm{X}$ & $\mathrm{XX}$ & 715 & $\mathrm{XX}$ & $\mathrm{X}$ & - & - & - \\
\hline & $\mathrm{X}$ & $\mathrm{X}$ & $\mathrm{XX}$ & * & $\mathrm{XXX}$ & $\mathrm{XX}$ & - & - & $\mathrm{X}$ \\
\hline \multirow[t]{17}{*}{ Apr } & $\mathrm{X}$ & $\mathrm{X}$ & $\mathrm{XX}$ & & 220 & 125 & - & - & $\mathrm{X}$ \\
\hline & $\mathrm{X}$ & $\mathrm{x}$ & $\mathrm{XX}$ & & 325 & 130 & - & - & $\mathrm{xx}$ \\
\hline & $\mathrm{X}$ & $\mathrm{XX}$ & $\mathrm{XXX}$ & & 445 & 190 & - & $\mathrm{x}$ & 560 \\
\hline & $\mathrm{X}$ & 230 & 55 & & 480 & 185 & $\mathrm{X}$ & $\mathrm{XX}$ & 410 \\
\hline & $\mathrm{XX}$ & 180 & 90 & & $320 * *$ & 140 & $\mathrm{X}$ & 105 & 130 \\
\hline & $\mathrm{XX}$ & 255 & 170 & & 275 & 135 & $\mathrm{XX}$ & 195 & $235^{* *}$ \\
\hline & $\mathrm{XX}$ & 350 & 170 & & 115 & 70 & $\mathrm{XX}$ & 175 & 125 \\
\hline & 380 & 305 & 285 & & 125 & 130 & $\mathrm{XX}$ & 350 & 95 \\
\hline & 235 & 140 & 90 & & 120 & 105 & $\mathrm{XX}$ & 270 & 105 \\
\hline & 280 & * & 90 & & & 120 & 105 & * & \\
\hline & 455 & & 90 & & & $130^{* *}$ & 105 & & \\
\hline & $300^{* *}$ & & 120 & & & 100 & 115 & & \\
\hline & 115 & & 95 & & & 130 & 215 & & \\
\hline & & & $135^{* *}$ & & & & 350 & & \\
\hline & & & & & & & 160 & & \\
\hline & & & & & & & $*$ & & \\
\hline & & & 110 & & & & 115 & & \\
\hline
\end{tabular}

lowed by F-2 of enclosure 3 by M-1 (April 13). The females of enclosure 3 were the last to come into heat, and the last mated female (F-1; April 21, by M-3) was also from enclosure 3. In addition, some mating efforts were observed; in enclosure 3 by M-1 (April 13), and in enclosure 1 by M-2 and M-3 (April 13).

\section{Whelping and communal helpers}

On May 19, female F-1 in enclosure 2 whelped into the nestbox close to enclosure 1. Two days later the kits were counted; 4 were alive and 5 dead. It was noted that the female carried the kits into the nestbox close to enclosure 3. On May 22, only one kit was alive, but even that was lost the next day. No communal helping was observed in the case of this female.
On May 29, female F-3 in enclosure 3 whelped 9 kits into the nestbox furthest from enclosure 2. Two days later, she carried the kits into the ground den which she had dug previously. In the same enclosure, F-2 whelped 5 kits on June 4. It was observed that male M-1 (father of the kits) often stayed close to F-2 and was inside the nest with the kits, too. He also brought feed to F-2. On June 12, F-1 of the same enclosure whelped into the nestbox but lost the kits soon. Shortly thereafter, both F-3 and F-1 started to nurse the kits of F-3 together without any aggressions or conflicts.

On June 3, females F-2 and F-3 in enclosure 1 whelped inside separate nestboxes. F-3 lost her kits on the same day, but all 10 kits of F-2 survived. After losing her own kits, F-3 began to communally nurse these kits with F-2. An inspection of the teats of both females revealed that both were actually able to nurse. It was additionally noted that the coat 
of F-3 was soiled by the urine of F-2. Both females were also observed to have a very close mutual relationship and friendly mutual contacts. When the kits were 2-3 weeks old, both females spent $22.2 \%$ of the daytime together inside the nestbox of F-2. For $38.9 \%$ and $29.2 \%$ of the day F-2 and F-3, respectively, were alone with the kits in the nestbox. The kits were left without the presence of an adult in the nestbox only $9.7 \%$ of day. Female F-1, which had no kits, was primarily an outsider as regards kit care. She tried to enter the nestbox of the kits a few times, but F-2 warded her off. When the kits were 12 days old, F-2 transferred some of them into another nestbox. Now both F-2 and F-3 nursed their own kit group. A few days later the kits were transferred back into the same nestbox, where F-2 and F-3 resumed their communal nursing. However, it was soon observed that F-2 carried one kit into a third nestbox, where F-1 started to care for it. Every now and then, F-2 or F-3 also visited that nestbox to nurse the kit. F-1 was not allowed to take care of any other kit except this one. Male M-1 (father) also sometimes spent shorter periods of time inside the nestbox with the kits. In addition, both M-1 and M-3 were observed to bring feed in front of the nestbox for the females.

\section{Discussion}

Observations both from the wild (JOHSON 1973, KLEIMAN 1967, MACDONALD 1979a) and from shed conditions (PEDERSEN and JEPPESEN 1992) show that foxes often prefer to defecate and/or urinate near territorial boundaries or close to neighbouring cages. Foxes employ such marking as a sign of their territory borders. This finding is also supported by the observations of the present study; as Fig. 1 clearly illustrates urinary marking was concentrated close to the walls of neighbouring enclosures. In addition, marking intensity was found to increase dramatically during the breeding season when tension between the individuals is also otherwise amplified (KORHONEN and ALASUUTARI 1992a). Marking activity was most pronounced in males, whose social rank is typically higher than that of females (KORHONEN and ALASUUTARI 1992a). In each enclosure the most dominant male (status 1) was the most intensive marker. Thus, there is substantial evidence that marking activity occurs in relation to the social status of males. In females living in groups, on the other hand, marking activity seems to be less important with respect to their social status, as reported previously by KORHONEN and ALASUUTARI (1992a). The significant increase in marking activity in March, observed in the present study, was due to increased hierarchical tension and reproductive behaviour preceding the breeding season (KORHONEN and AlASUUTARI 1992a).

As Tables 2-3 show, the daily number of social contacts is related to an animal's social status as judged by dominant/submissive behaviour. Moreover, the highest-ranking male of each group could be easily identified by virtue of its highest number of mutual contacts, as described previously (KORHONEN and ALASUUTARI 1992a). Thus, it is obvious that the daily number of social contacts is a fairly good indicator of an animal's social status, at least near to the breeding season when mutual tension between individuals is most pronounced.

The behavioural activity of the animals increased towards the onset of the breeding season. Especially the locomotor activity of the males was marked at that time. The higher activity level of males is in relation to their larger number of social contacts and distinct status behaviour during the breeding season (KORHONEN and ALASUUTARI 1992a). On the other hand, the most dominant male was not necessarily the most active one according to the present study. It was observed that the 2ndranking male often tried to actively initiate contacts especially with females, but the dominant male or the female in question prevented it. Therefore, the 2nd-ranking male was often restless (running around) which was manifested in the form of an increased activity level. ANGERBJÖRN et al. (1991) noticed that it was precisely the 2 nd-ranking males that were most active and aggressive also in food scavenging experiments.

The present mating data are partly unreliable because it was not possible to follow the mating behaviour of the foxes continuously. However, the time of day when the monitoring was performed 
Table 5. Summary of females' reproductive results in ground enclosure experiments according to the present study $(1,2,3)$ and previous studies (4,5: KORHONEN and AlasuUtari 1991a,b, 6: KORHONEN and AlaSUUTARI 1992a).

\begin{tabular}{|c|c|c|c|c|}
\hline Exp. & female & Heat cycle & Mating & Reproductive success \\
\hline \multirow[t]{3}{*}{ (1) } & F-1 & normal & $?$ & \multirow{3}{*}{$\begin{array}{l}\text { not pregnant } \\
\text { whelped, kits survived } \\
\text { whelped, kits lost* }\end{array}$} \\
\hline & F-2 & normal & yes & \\
\hline & F-3 & normal & yes & \\
\hline \multirow[t]{3}{*}{ (2) } & F-1 & normal but early & yes & \multirow{3}{*}{$\begin{array}{l}\text { whelped, kits lost** } \\
\text { not pregnant } \\
\text { not pregnant }\end{array}$} \\
\hline & F-2 & normal & $?$ & \\
\hline & F-3 & normal & $?$ & \\
\hline \multirow[t]{3}{*}{ (3) } & F-1 & normal but late & yes & \multirow{3}{*}{$\begin{array}{l}\text { whelped, kits lost*** } \\
\text { whelped, kits survived } \\
\text { whelped, kits survived }\end{array}$} \\
\hline & F-2 & normal & yes & \\
\hline & F-3 & normal & yes & \\
\hline \multirow[t]{2}{*}{ (4) } & F-1 & started normally & no & \multirow{2}{*}{$\begin{array}{l}\text { escaped at proestrus } \\
\text { escaped at proestrus }\end{array}$} \\
\hline & F-2 & started normally & no & \\
\hline \multirow[t]{3}{*}{ (5) } & F-1 & normal but late & no & \multirow{3}{*}{$\begin{array}{l}\text { not pregnant** } \\
\text { pregnant but aborted***** } \\
\text { whelped, kits survived }\end{array}$} \\
\hline & $\mathrm{F}-2$ & normal & yes & \\
\hline & F-3 & normal & yes & \\
\hline \multirow[t]{4}{*}{ (6) } & F-1 & started normally & no & \multirow{4}{*}{$\begin{array}{l}\text { escaped at proestrus } \\
\text { pregnant but aborted } \\
\text { not pregnant } \\
\text { whelped, kits lost }\end{array}$} \\
\hline & F-2 & normal & yes & \\
\hline & F-3 & only proestrus & no & \\
\hline & $\mathrm{F}-4$ & normal & yes & \\
\hline
\end{tabular}

\footnotetext{
* acting as helper for F-2

** escaped before whelping, was caught and returned

$* * *$ acting as helper for F-3

$* * * *$ escaped after whelping of F-3
}

(8.00-11.00 a.m. and 1.00-4.00 p.m.) is the time when matings most often occur according to farming practice. Nevertheless, it is quite obvious that some mating data were missed, which means that the estimation of the relationship between the foxes' social status and mating success is difficult. In our previous study (KORHONEN and ALASUUTARI 1992a) the most dominant male was also found to be the predominant breeder, although breeding efforts were observed in lower-ranking males as well. In that experiment only the most dominant female whelped but lost the kits quite soon after whelping.

Table 5 summarizes the reproductive success in our present and previous enclosure experiments. It is obvious that the reproduction of arctic blue foxes is not very successful under the studied (Exps.1-6) group-living conditions because the kits of only 4 $(22 \%)$ vixens (Exps. 1,3,5) of a total of 18 survived. The main reason for the poor reproductive perform- ance may have been due to the structure of the groups. Often groups are formed in the wild by parents and their kits or other close relatives (MACDONALD 1979b), but the individuals in our groups (Exps. 1-6) in many cases were not related. Another explanation for the kit losses and poor reproductivity in the groups could be the social tension and pronounced dominance relations between the animals.

MACDONALD (1979b) performed a comprehensive study on the social regulation of reproductive performance among red fox groups in captivity. However, it was not possible accurately to measure the sexual state and heat development of the groupliving vixens in that study. It was therefore also difficult to propose any final explanation for the reproductive suppression of subordinate vixens. In the present study, on the other hand, the data on electrical resistance in the vaginal tract provide a 
better perspective for estimating such regulatory mechanisms (c.f. MÖLLER 1980). It now seems obvious that there are several mechanisms which prevent all of the vixens of the group from breeding. Such prevention can already begin during the breeding season when all females do not necessarily come into heat, but may reach the level of proestrus only (Exp. 6). The timing of the onset of the heat cycle (early, late) can be another influencing factor (Exps. 2,3,5). In addition, in spite of a normal heat cycle some females do not necessarily become pregnant at all (Exps. 1,2,5,6) or become pregnant but abort (Exps. 5,6).

Although the group members cohabited well during the autumn and early winter, pronounced aggressive encounters suddenly occurred as the breeding season approached. This also led to some bitings and may also be one reason for the escape attempts observed. Aggressive behaviour, bitings and escapes were similarly observed in our previous study (KORHONEN and ALASUUTARI 1992a) near the breeding season. Thus, it is obvious that in addition to physiological mechanisms, behavioural factors also have a role in the prevention of breeding of surplus animals in the group.

The presence of non-breeding surplus adults as helpers has been best documented by MACDONALD (1979b), who observed in captive red foxes that the surplus vixens could feed, guard, groom and play with the kits. There are some other observations of such behaviour in wild red and arctic foxes (HERSTEINSSON and MACDONALD 1982, KULLBERG and ANGERBJÖRN 1991). The present study clearly showed that surplus vixens may also nurse the kits together with the original vixen, and that an additional third vixen may participate in the care of the kits. Thus, both non-breeding and breeding vixens seem to be capable of acting as helpers as observed in Exps. 1 and 3. The helping role of males is that of bringing feed. It is tempting to conclude that a system of co-operative assistance is a part of the survival strategies of fox societies.

\section{References}

Angerbuörn, A., Almqvist, L., Kullberg, C., Linkowski, W., RYgme, H. \& TANNERFEDT, M. 1991. Social behaviour of arctic foxes in relation to food distribution. In: Angerbjörn, A. (ed.). Arctic Fox Biology. The 1st International Arctic Fox Meeting, Ammarnäs, Sweden.

BANFIEld, A.W.F. 1977. The mammals of Canada. University of Toronto press, Toronto.

Eberhardt, L.E., Garrott, R.A. \& Hanson, W.C. 1983. Winter movements of arctic fox, Alopex lagopus, in a petroleum development area. Journal of Wildlife Management 46: 183-190.

Fox, M.W. 1969. The anatomy of aggression and its ritualization in Canidae: a developmental and comparative study. Behaviour 35: 242-258.

Garrott, R.A., Eberhardt, L.E. \& Hanson, W.C. 1984. Arctic fox denning behaviour in north Alaska. Canadian Journal of Zoology 62: 1636-1640.

Hersteinsson, P. 1991. Pair bonds and territory fidelity among arctic foxes. In: Angerbjörn, A. (ed.). The 1st International Arctic Fox Meeting, Ammarnäs, Sweden.

— \& MacDonald, D.W. 1982. Some comparisons between red and arctic foxes, Vulpes vulpes and Alopex lagopus, as revealed by radio tracking. Symposia of the Zoological Society of London 49: 259-289.

Johson, R.P. 1973. Scent marking in mammals. Animal Behaviour 21: 521-535.
KLeIMAN, D.G. 1967. Some aspects of social behaviour in the Canidae. American Zoologist 7: 365-372.

Korhonen, H. \& AlasuUtari, S. 1991a. Features of social behaviour in arctic fox group housed in large enclosure. Scientifur 15: 201-210.

— \& AlasuUtari, S. 1991b. Social behaviour in arctic blue fox. NJF seminarium nr 200 rörande pälsdjursproduktion. Esbo, Finland.

— \& AlasuUtari, S. 1992a. Hierarchical development in captive arctic blue fox pack. Scientifur 16: 13-22.

— \& AlasuUtari, S. 1992b. Induced changes in social relationships of arctic blue foxes. Scientifur 16: 181-188.

— \& Al.ASUUTARI, S. 1993. Episodes of kit carrying. Scientifur 17: 27-29.

KuLlBerg, C. \& AngerbJörn, A. 1991. Social behaviour and cooperative breeding in arctic foxes, in a semi-natural environment. In: Angerbjörn, A. (ed.). Arctic Fox Biology. 1st International Arctic Fox Meeting, Ammarnäs, Sweden.

MacDonald, D.W. 1979a. Some observations and field experiments on the urine marking behaviour of the red fox, Vulpes vulpes L. Zeitschrift für Tierpsychologie 51: 1-22.

- 1979b. Helpers in fox society. Nature 282: 69-71.

- 1984. The Encyclopedia of Mammals. London: George Allan and Unwin.

MOLLER, O. 1980. Measurement of electrical resistance of the 
vaginal tract to determine the optimum time to mate blue fox, silver fox and raccoon dog. Norsk Pelsdyrblad 54: 591-595.

Pedersen, V. \& Jeppesen, L.L. 1992. Defecation patterns in the cage and in various types of whole-year shelters in farmed silver foxes and blue foxes. Scientifur 16: 275284.
W AKELY, L.G. \& MALLORY, F.F. 1988. Hierarchical development, agonistic behaviours, and growth rates in captive arctic fox. Canadian Journal of Zoology 66: 1672-1678.

Manuscript received August 1993

\title{
SELOSTUS
}

\section{Sosiaaliset suhteet ja lisääntyminen erilaisissa siniketturyhmissä}

\author{
HANNU KORHONEN $^{1}$ ja SAKARI AlaSUUtARI ${ }^{2}$ \\ ${ }^{1}$ Maatalouden tutkimuskeskus ja ${ }^{2}$ Helsingin yliopisto
}

Tutkimuksessa selvitettiin ryhmän rakenteen vaikutusta sinikettujen sosiaalisiin suhteisiin vieroituksesta läpi talven penikointiin saakka. Tulokset osoittivat, että urokset ovat yleensä dominoivia naaraisiin nähden. Uroksilla on myös naaraita enemmän sosiaalisia kontakteja. Urosten painonkehitys on naaraita hieman suurempi. Kettujen, etenkin urosten, liikuntaaktiviteetti nousee selvästi lisääntymisaikana. Myös virtsaamiskäyttäytyminen on korostetun voimakasta lisääntymiskaudella. Dominoivat urokset ovat kaikkein intensiivisempia virtsaajia. Virtsaa käytetään reviirin merkitsemiseen sekä oman sosiaalisen aseman ja seksuaalisen tilan ilmaisemiseen. Ryhmäkasvatettujen naaraiden kiimankehitys ei ole synkronoitua läheisestä keskinäisestä sukulaisuussuhteesta huolimatta. Sellaiset käyttäytymispiirteet kuten karkaamiset, aggressiot ja puremat korostuvat lisääntymiskaudella johtuen sosiaalisten jännitteiden kasvusta. Osa ryhmän naaraista ei joko saa pentuja tai hävittäả ne. Silti tällaiset naaraat voivat toimia penikoivien emojen apuna pentujen hoidossa. 